\title{
A scientific note on the first successful establishment of the monophlebine coccid Marchalina hellenica (Coccoidea, Margarodidae) on the fir tree (Abies cephalonica)
}

\author{
Nikolaos BACANDRITSOS* \\ Institute of Veterinary Research of Athens, NAGREF, 25 Neapoleos Street Agia Paraskevi, \\ 15310 Athens, Greece
}

(Received 22 April 2000; revised 2 December 2001; accepted 18 December 2001)

honeydew / Marchalina hellenica / fir tree / Abies cephalonica

The honeydew produced by insects feeding on conifers is an important source of honey in Greece. Sixty \% of the annual honey production in Greece comes from the honeydew produced by the scale insect Marchalina hellenica (Gennadius) which lives on Pinus brutia (Ten) and $P$. halepensis Miller (Bodenheimer, 1953; Marotta and Priore 1992 [1994]) and more rarely on $P$. pinea $\mathrm{L}$. and $P$. nigra (Arnold) (Avtzis, 1985). Five \% of Greek honey production comes from the honeydew produced by other scale insects such as Physokermes hemicryphus (Dalman) and Eulecanium sericeum (Lindiger) and the aphid Mindarus abietinus (Koch). These insects live on Abies cephalonica (Loudon) and A. borisiiregis (Mattf) (Santas, 1983). According to 1992 Ministry of Agriculture statistics, forests of pine trees account for $26 \%$ of the total forest area in Greece, and those of fir trees for $16 \%$. In an attempt to increase honey production in Greece, the Ministry of Agriculture set out to introduce $M$. hellenica into pine and fir forests that did not have populations on scale insects.

$M$. hellenica lives in the cracks and under the scales of bark on pine trees, concealed in large quantities of the white cotton-like wax that it exudes. It feeds on sap of pine trees and produces a viscous type of honeydew that is clear to reddish-pink in color and which honey bees gather to produce honey. $M$. hellenica has one generation per year (Fimiani and Sollino, 1994; Priore et al., 1996) and eggs are laid in April or May - depending on climatic conditions - in cracks of the bark in a white cotton-like egg mass. First instars hatch ca. 20 days after eggs are laid and they move to shaded feeding sites in cracks of the bark on trunk or main branches, and begin producing a waxy covering. From May until the beginning of October, the insect molts twice and becomes a third instar or intermediate female. This instar lasts from mid-October until the beginning of the following May. There is a marked increase in food intake during this period with a concomitant increase in body size and honeydew production. In contrast, the adult female does not feed, it lives for a short time, and her primary function is to lay eggs.

The objective of our study was to try to establish $M$. hellenica on a conifer different from Pinus spp., the establishment encompassing the sucessful succesion of all life stages until and including reproduction. We initially focused on the region of mount Fteri (longitude 22 $4^{\circ}$ '40"E, latitude $38^{\circ} 9^{\prime} 10^{\prime \prime} \mathrm{N}$, altitude $700 \mathrm{~m}$ ) in May of 1993 and 1994. We artificially introduced $M$. hellenica from neighboring pine trees (P. halepensis) to 200 fir trees (A. cephalonica). In May of 1995 to 1997, a second more intensive introduction was undertaken on fir trees in the mountains of Menalo (longitude 22 $13^{\prime} 10^{\prime \prime} \mathrm{E}$, latitude $37^{\circ} 37^{\prime} 40^{\prime \prime} \mathrm{N}$, altitude $1200 \mathrm{~m}$ ) and Helmos (longitude 22०11'30"E, latitude $37^{\circ} 59^{\prime} 30^{\prime \prime} \mathrm{N}$, altitude $2200 \mathrm{~m}$ ), two regions without pine tree. Specifically, in a 10 ha forest of fir trees in Menalo and a similar 5 ha tract in Helmos, infested pine branches were placed in fir trees at the rate of one pine branch in every 10 fir trees. Two introductions were carried out, one with second and third instar intermediate

\footnotetext{
* Correspondence and reprints

E-mail: Bac.ivra@nagref.gr
} 


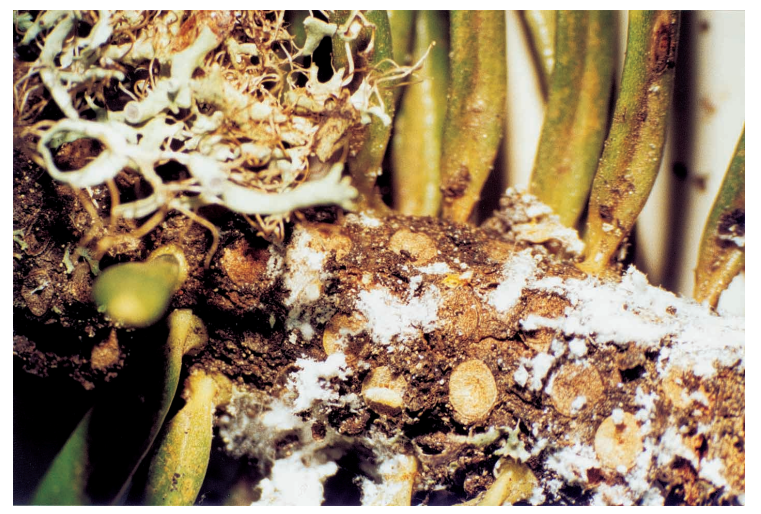

Photo 1. First instar of Marchalina hellenica on a fir tree Abies cephalonica. females and one with adult females. The pine branches were cut into pieces not more than $10 \mathrm{~cm}$ in diameter and $30 \mathrm{~cm}$ in length, and each of them harbored at least $5 \mathrm{M}$. hellenica. Those branches were attached around the trunk of each fir tree. The introduction sites were checked three times a year to determine if the insect was established.

The first verified establishment of $M$. hellenica on fir trees was found in the mountains of Menalo and Helmos in 1997 (Photo 1). In Helmos, the percentages of successful establishment in 1995 were $85.6 \%$ of the trees infected with second and third instar females and $86.7 \%$ of the trees infected with adult females. In 1996, the percentages were $76.7 \%$ and $84.5 \%$, respectively. In Melano, establishment took place but the results were not quantified. No such establishment has been observed on Mount Fteri where pine and fir trees occur together. It is unknown why the establishment of M. hellenica was successful in Melano and Helmos, but it may be that the absence of pine trees, the primary host of $M$. hellenica, was an essential factor. Also it was known that the coccid was monophagous, but, in view of this establishment on fir trees, we conclude that it is a stenophagous spieces.

It is the first time that M. hellenica has been reported to feed on fir trees. The appearance of the affected firs resembles that of pines and at the site of the establishment, there is a large quantity of white, cotton-like, waxy substance. In spring and autumn, honey bees visit the affected fir trees to gather honeydew and in 1999, a small quantity of honey was gathered from fir trees that had been inoculated. It is worth noting that $M$. hellenica has now spread on fir trees several hundred meters from the original site of in- troduction. We believe that the successful establishment of $M$. hellenica in fir tree forests will be important in increasing honey production in Greece. However, the possible weakening effect of $M$. hellenica on fir trees is also under further investigation as is the possible impact of the new appearance of fir trees on locals and tourists.

Note scientifique sur le premier établissement réussi du coccide monophlébine Marchalina hellenica (Coccoidea, Margarodidae) sur le sapin (Abies cephalonica).

Wissenschatliche Notiz über die erste erfolgreiche Niederlassung des monophlebine coccid Marchalina hellenica (Coccoidea, Margarodidae) auf den Tannenbaum (Abies cephalonica).

\section{REFERENCES}

Avtzis N. (1985) Marchalina hellenica (Monophlebus hellenicus) Gen. Greece's most important honeybearing insect, Dasiki Erevna 1, 51-64 (in Greek).

Bodenheimer F.S. (1953) The coccoidea of Turkey III, Istanbul Univ. Fac. Sci. Rev. Ser. B Tom. XVIII, 2, 91-164 (152-154).

Fimiani P., Sollino G. (1994) An exotic insect dangerous to the native plants of the island of Ischia, Inf. Agrar. 50, 65-68.

Marotta S., Priore R. (1992 (1994)) Morphological notes on Marchalina hellenica (Genadius) (Homoptera Coccoidea Margarodidae), Boll. Lab. Entomol. Agrar. Filippo Silvestri 49, 195-202.

Priore R., Marotta S., Sollino G. (1996) The life cycle of Marchalina hellenica (Gennadius) (Homoptera Coccoidea Margarodidae) on Pinus spp. in the Island of Ischia, Boll. Lab. Entomol. Agrar. Filippo Silvestri 52, 35-41.

Santas L.A. (1983) Insects producing honey dew exploited by bees in Greece, Apidologie 14, 93-103. 